\title{
A CONTRIBUTION TO THE DEBATE ON THE REPUBLIC OF CROATIA AS A SECULAR STATE AND ON THE TERMS SECULARIZATION AND SECULARISM**
}

Summary: In this paper, the author addresses the question of separation of state and church in the Republic of Croatia. There are those who argue that Croatia is a secular state, and there are those who argue the opposite. In order to analyze the relationship of state and church in the Republic of Croatia, the author first analyzes the constitutional determination of separation of state and church. He then analyzes different models of state-church relations in order to provide a theoretical frame for the inclusion of the Republic of Croatia in a corresponding model. He defines the term "secularism" and distinguishes this term from two other terms: "secular" and "secularization". Through examples and research done by other authors he shows that there is no common definition of secularism and that it is not possible to define it in a way that would apply in every legal system. The author shows that those who argue that Croatia is not a secular state are wrong. However, he also shows that the meaning that "secularists" in Croatia ascribe to the term "secularism", on the basis of which they claim that Croatia is a secular state, is also flawed. Namely, secularism in the context of Croatia does not have the same meaning as that in France - the banning of religion from the public sphere. Croatia has built a cooperation model of church and state relations in which church and state are separate, but the state is obliged to cooperate with and assist religious communities in their work.

Keywords: $\quad$ secular, secularism, secularization, separation of state and church

\footnotetext{
Frane Staničić, PhD, Associate Professor, Faculty of Law, University of Zagreb, Trg Republike Hrvatske 14, 10000 Zagreb, Republic of Croatia. E-mail address: frane.stanicic@pravo.hr. ORCID: https//: orcid.org/0000-0001-8304-7901.

** This paper was written within the project of the Faculty of Law Zagreb titled "New Croatian Legal System".
} 


\section{INTRODUCTION}

Questions relating to secularization, secularism of the state and the aspect of secularism applied in a specific society have been the subject of numerous sociological, scientific-political and legal debates in the world, which indicates the importance and extraordinary topicality of those questions. Recently, in our domestic public space, we can witness an intense debate on the question of whether the Republic of Croatia is a secular state. ${ }^{1}$ The responses largely reflect the ideological commitment of the response provider. Namely, almost all participants in the debate on whether the Republic of Croatia is a secular state approach the topic solely from their point of view, refusing to see the bigger picture. These issues are approached ideologically, politically and exclusively. Therefore, in order to answer the question whether the Republic of Croatia is a secular state, it is necessary to analyze the relevant provisions of the Constitution of the Republic of Croatia, to carry out an appropriate comparative analysis, and then to define the terms "secularism", "secularization" and to determine whether the terms "secularism" and "secularity" are synonyms. Only after we have determined the subject of the debate can we give a decisive and unambiguous answer to the question whether the Republic of Croatia is a secular state. Perhaps more important than answering that question - whether the Republic of Croatia is a secular state - is answering the question of what the relationship between the Republic of Croatia and its religious communities should be like. So, if the state has established a cooperation model $^{2}$ (see more on this infra) of the state-church relationship, does it cooperate equally with everyone it should, that is, if it has established a system of strict separation of state and church, does it adhere to that rule concerning all actors?

Likewise, one must distinguish between faith and religion. Faith is a personal belief and it is the subject of our inner being. Religion is an organized, organizationally structured system of ideas that, as a rule, rests on solid forms and a hierarchical structure. In this paper, I analyze the relationship between state and religion, that is, between the state and the religious communities as organizational forms within which one's faith is manifested in an organized manner and which enter different relations with the state. In this context, when I talk about the separation of state and church, I refer to the position of religious communities as the bearers of religion as an organized system of ideas. It should also be emphasized that I believe that a state in which there is a separation of state and church necessarily belongs to secular states.

$1 \quad$ Puhovski for Index:, Croatia is not constitutionally a secular state; here are three arguments for this https://www.index.hr/vijesti/ clanak/puhovski-za-index-hrvatska-ustavno-nije-sekularna-drzava-evo-tri-argumenta-za- to/990914.aspx, The Head of the Department for Constitutional Law has just confirmed that Croatia is a secular state, https://www.telegram.hr/politika-kriminal/ upravo-nam-je-i-sef-katedre-za-ustavno-pravo-potvrdio-kako-je-hrvatska-sekularna-drzava/, An esteemed professor of constitutional law has just given a lesson to the Chief Editor of Glas Koncila: "According to the Constitution, Croatia is a secular state and that's that!", https://net.hr/danas/hrvatska/ugledna-profesorica-ustavnog-prava-poducila-urednika-glasa-koncila-hrvatska-jeprema-ustavu-sekularna-drzava-i-tocka/, Glas Koncila: Croatia is not a "secular" state, http://hr.n1info.com/ a245353/Vijesti/ Glas-Koncila-Hrvatska-nije-sekularna-drzava.html, The day when all were wrong: is Croatia a secular state? http://hrvatska-danas. com/2017/08/28/dan-kad-su-svi-bili-u-krivu-je-li-hrvatska-sekularna-drzava/The secularity of the Croatian state: A problem avoided both by the left and the right http://www.novilist.hr/ Vijesti/Hrvatska/Sekularnost-hrvatske-drzave-Problem-od-kojegbjeze-i-lijevi-i-desni. What kind of Church in what kind of Croatia? The presence of the Church is a legitimate fact - but what should it be like? https://www.glas-koncila.hr/kakva-crkva-kakvoj-hrvatskoj-prisutnost-crkve-legitimna-cinjenica-kakva-biti/ (19. 3. 2019).

2 In the paper I will show that the formal status of a religious community, which is, for example, the state religion, does not always necessarily negate the secular character of the state. 
What we cannot exclude when talking about the relationship between church and state is a very simple fact, that religious communities are present in society, which cannot be ignored. Likewise, it should be pointed out, as Malović states, that the actual relationship between church and state, both in history and today, has rarely completely satisfied both sides. ${ }^{3}$

\section{UNDERSTANDING THE SEPARATION OF STATE AND CHURCH IN THE REPUBLIC OF CROATIA}

In our country, the separation of state and church, in the spirit of Art. 41 of the Constitution, is often defined in the strictest ideological meaning of secularism that originates in France, that is, in the constitutional designation of the French Republic as a secular (laïque) state $^{4}$ (see more on that infra).

On the other hand, in our public space, there are such interpretations of Art. 41 of the Constitution that emphasize only its second section, which stipulates the obligation of the state to assist and cooperate with religious communities and the conclusion drawn from this is that the Republic of Croatia is not a secular state. ${ }^{5}$ However, the answer, regardless of the direction of interpretation, is neither simple nor straightforward.

In the Constitution of the Republic of Croatia, the character of the Croatian state regarding the relationship between the state and the church is regulated in a more complex way than in the case of the French Constitution. Namely, the subject of the regulation of Art. 1 Section 1 of the French Constitution is stipulated by Art. 1 Section $1,{ }^{6}$ Art. $14^{7}$ and Art. $41^{8}$ as well as Art. $40^{9}$ in connection with Art. 17 Section $3^{10}$ of the Constitution of the Republic of Croatia. The

Malović, N., Laičnost - prilike i zablude [Laicism - opportunities and misconceptions], Crkva u svijetu, Vol. 50, No. 3, 2015, p. 428.

4 “(...) The word laicism comes from the Greek word which 'denotes a unit of the population that is considered an indivisible whole'. Therefore, a layperson is one who is equal to everyone else in the supposed situation of lacking any privilege. (...) The history of relationships between the church, especially the Catholic Church, and the state in France eventually ended with a radical separation of the public and private spheres, leaving religion in the private lives of individuals, whether strictly personal or collective. (...) Laicism (Secularity), therefore, is a guarantee of the public sphere, a universal space reserved for what is common to all and is, therefore, a prerequisite for the establishment of a united political community. (...) Accordingly, secular space is neither poly-confessional nor mono-confessional, it is non-confessional; and may be violated by the overt or covert privilege of one or more confessions." Špehar, H., Laičnost: etimologija i historijat [Laicity: etymology and history], Politička misao, Vol. 48, No. 1, 2011, p. 121-123.

5 Puhovski for Index: Croatia is not constitutionally a secular state; here are three arguments for this, https://www.index.hr/vijesti/ clanak/puhovski-za-index-hrvatska-ustavno-nije-sekularna-drzava-evo-tri-argumenta-za-to/990914.aspx (19. 3. 2019), Miklenić is right in saying that constitutionally Croatia is not a secular state https://www.vecernji.hr/vijesti/miklenic-je-u-pravu-dahrvatska-po-ustavu-nije-sekularna-drzava-1190859 (19. 3. 2019), Glas Koncila: Croatia is not a "secular" state, http://hr.n1info. com/a245353/Vijesti/Glas-Koncila-Hrvatska-nije-sekularna-drzava.html (19. 3. 2019).

6 "The Republic of Croatia is a unitary and indivisible democratic and social state."

7 "All persons in the Republic of Croatia shall enjoy rights and freedoms, regardless of (...) religion (...). All persons shall be equal before the law."

8 "All religious communities shall be equal before the law and separate from the state. Religious communities shall be free, in compliance with the law, to publicly conduct religious services, open schools, colleges or other institutions, and welfare and charitable organisations and to manage them, and they shall enjoy the protection and assistance of the state in their activities".

$9 \quad$ "Freedom of conscience and religion and the freedom to demonstrate religious or other convictions shall be guaranteed."

10 "Even in cases of clear and present danger to the existence of the state, no restrictions may be imposed upon the provisions of this Constitution stipulating the (...) freedom of (...) religion." 
constitutional regulation of the relationship between the state and the church in the Republic of Croatia is further complicated by the provision of Art. $134^{11}$ of the Constitution due to four treaties concluded between the Republic of Croatia and the Holy See.

As already stated, supporters of one and the other idea of regulating relations between the state and the church in the Republic of Croatia emphasize one specific constitutional provision in order to substantiate their own opinion. However, we should remind ourselves of the Constitutional Court's position concerning the text of the Constitution as a whole:

“(...) The constitution forms a single whole. It cannot be approached in such a way that one provision is extracted from the whole of the relations established by it, and then it is interpreted separately and mechanically, regardless of all other values protected by the Constitution. The Constitution possesses internal unity and the meaning of the individual part is related to all other provisions. When viewed as a unity, the Constitution reflects individual overarching principles and fundamental decisions in connection with which all its individual provisions must be interpreted. Therefore, no constitutional provision can be taken out of context and interpreted independently. In other words, every single constitutional provision must always be interpreted in accordance with the highest values of the constitutional order that underlie the interpretation of the Constitution itself. These are freedom, equality, national and gender equality, peace-making, social justice, respect for human rights, inviolability of property, preservation of nature and human environment, the rule of law and a democratic multi-party system (Article 3 of the Constitution)." ${ }^{12}$

Also, it should be borne in mind that in its decision U-VIIR-158/2015 of 21 April 2015, the Constitutional Court of the Republic of Croatia stated the following: ${ }^{13}$

"Unlike individual state goals (by which we mean constitutional norms with legally binding effect that prescribe a permanent observance or fulfilment of certain state tasks in the form of positive or negative obligations), constitutional principles determine the structure and essence of the Croatian state. Croatia may remain as it is even if its individual state goals are removed from its Constitution, but it will not remain the same state community if one of the structural constitutional principles were abolished or amended."

In this light, the question arises whether the principle of separation of state and church under Art. 41 (1) of the Constitution of the Republic of Croatia is a constitutional principle in the sense of the cited decision of the Constitutional Court of the Republic of Croatia. That is, would "Croatia remain as it is" even if the principle of separation of state and church were removed from its Constitution?

I believe, that, so far, two fundamental questions have emerged in the text that need to be answered in this paper:

11 "International treaties which have been concluded and ratified in accordance with the Constitution, which have been published and which have entered into force shall be a component of the domestic legal order of the Republic of Croatia and shall have primacy over domestic law. Their provisions may be altered or repealed only under the conditions and in the manner specified therein or in accordance with the general rules of international law". 
1. Which model of state-church relationship was chosen by the framers of the Croatian Constitution?

2. Does the principle of the separation of religious communities from the state mean that Croatia is a secular state, and if so, what does "the secularity of the Croatian constitutional state" mean in the national constitutional framework?

\section{MODELS OF STATE-CHURCH RELATIONS}

"By following the established division, we can say that in theory (and practice) three general models of church-state relations have been identified:

1. The model of the state or national churches,

2. The cooperative or the concordat model,

3. The model of strict separation of church and state (the separation model)." ${ }^{14}$

Of course, these three above listed models are not the only "pure" models. That is, they can be elaborated and combined, "for example, into six models of church-state relations:

1. Aggressive animosity between church and state (communist regimes),

2. Strict separation in theory and practice (France),

3. Strict separation in theory but not in practice (USA),

4. Separation and cooperation (FR Germany),

5. Formal unity, but with substantial division (UK, Denmark, Israel, Norway), and

6. Formal and substantial unity (IR Iran, Saudi Arabia - where, of course, there is a substantive unity of the respective Islamic communities and the state)" ${ }^{15}$

A crucial thing is - is there a separation of state and religion in all the above models, or is the state secular in all those models? It is clear, that this question can be raised specifically in the system of state or national churches. Indeed, can it be said at all that the model of a state or national church implies a secular state, that is, that any form of secularism is applied in the respective state?

Nevertheless, there are studies which have shown that the correlation between the existence of official religious belief and actual state policy may be weak. ${ }^{16}$ As an illustrative example of this we can state Brugger's church-state relationship model of "formal unity, but with substantial division" in which there is no formal separation of church and state, but in practice they are anything but unified.

14 Sokol, T.; Staničić, F., Pravni položaj Katoličke Crkve kao gospodarskog subjekta u pravu Europske unije i hrvatskom pravu [Legal Status of the Catholic Church as an Economic Entity in EU and in Croatian Law], Zbornik Pravnog fakulteta u Zagrebu, Volume 68, No. 3-4, 2018, p. 44. Zrinščak, S., Religija i društvo [Religion and Society], in: J. Kregar et al., Uvod u sociologiju, Zagreb, 2014, p. 505.

15 Sokol; Staničić, op. cit., in fn. 14, p. 44. Brugger, W., On the Relationship between Structural Norms and Constitutional Rights in Church-State-Relations, in: Brugger, W.; Karayanni, M. (ed.), Religion in the Public Sphere: A Comparative Analysis of German, Israeli, American and International Law, Berlin - Heidelberg - New York 2007, p. 31.

16 Fox, J., Separation of Religion and State and Secularism in Theory and Practice, Religion State and Society, London, Vol. 39, No. 4, 2011, p. 384. 
Based on the criterion of separation, Fox sets out a basic model and three additional models of state-church relations. The basic model is divided into the model of separation of state and church and the model of secularism- laicism. This difference at the basic level stems from constitutional texts. Namely, some constitutions declare the state as secular or lay, while some constitutions declare the separation of state and church. ${ }^{17}$ The first basic model means a system of separation that represents state neutrality towards religion, in which the state, at least officially, does not favour any religion, but it does not limit the presence of religion in the public sphere either. The second basic model denotes a system of laicism which is specific for the state that not only does not support any religion but also limits the presence of religion in the public sphere. Based on this approach, the difference between the approach to secularism elaborated by Fox by using additional three models can be clearly demonstrated.

The first additional model is the model of absolute separation of state and church. This model requires that the state neither support nor interfere with any religion. According to Fox, this model is the most extreme because it does not allow any state interference in religion and vice versa. The second additional model is a neutral political model which requires that the state by its activities does not help or hinder any life plan or lifestyle more than any other, and therefore the activities of the state should be neutral. In this model, the state may restrict or support religious freedoms, provided that the ultimate outcome is the same for all religions. The third additional model is the model of exclusion of ideals, which requires that the state be barred from justifying its activities based on its preference for a specific lifestyle. This model is focused on intent rather than outcome. Within this model, different religions can be treated differently, provided there is no specific intention to support or obstruct any particular religion. ${ }^{18}$

From Fox's very interesting research, it emerged that it is almost irrelevant what states declare in their constitutions or their specific legal orders; it is the actual conduct of the state which is almost exclusively relevant. According to Fox's research, in which he used constitutional declarations that the state is secular and declarations of separation of religion and state as criteria for the rigorous model of secularism-laicism and the separation of religion and state, not even France and Turkey (commonly referred to in the literature as secularized, lay states) meet the criteria to fit into this model. Likewise, Germany, Italy and Spain, which emphasize in their constitutions the separation of church and state, do not meet the criteria for inclusion in this model. ${ }^{19}$

Therefore, it seems correct to say that it is not important at all whether societies are secularized, but whether the states are indifferent or neither "secular" nor "religious" but equidistant to both, respecting the autonomy of both spheres. ${ }^{20}$ Instead of promoting "strict separation" and the principles of neutrality and a "religiously blind" state, it may be necessary to reconceptualize liberal principles and create alternative regimes for the management of

\footnotetext{
17 Ibid., p. 385.

18 Ibid., p.p. 385, 386.

19 Ibid., p. 396.

20 Bader, V., Introduction to secularism or democracy? Associational governance of religious diversity, Krisis, Journal for contemporary philosophy, Amsterdam, Vol. 9, No. 1, 2008, p. 20.
} 
religion. ${ }^{21}$ Of course, states must be at least relatively autonomous from churches, as well as churches from state control, whereby even a minimalist interpretation requires a threshold of institutional, organizational and semantic differentiation between secular power, states, politics, politicians and "spiritual" powers, organized religions and religious leaders. ${ }^{22}$ Some authors believe that the debate about whether a specific state is secular or not is completely off the mark and that the real debate should be whether it is a "decent and/or liberal-democratic state". ${ }^{23}$

Besides, it should be emphasized that "the relationship between the state and the church arising from secularization and the idea of a neutral state concerning worldview cannot be reduced to the institutional separation of Church and state. The separation of state and church means that their power managements are separated. Churches do not govern political authority, and the state does not govern any authority in the spiritual or religious sphere. The state cannot be neutral towards the area of confessionalism and worldview. Therefore, we can speak exclusively of inclusive neutrality, which means that the state is concerned with the legal framework for the pluralistic inclusion of religion and worldview in public life. This is also a basis for the relations between churches and the state emerging in two main characteristic forms in contemporary Europe: on the one hand, the separation of the state and the church that extends secularization to the public sphere (France and the Netherlands) and, on the other, the connection of the state and the church by a special contractual transfer of some public authorities to churches and/or religious communities (Austria, Germany, Italy, Spain, etc.). In these states, the level of publicity is clearly separated from the state, and the state does not extend secularization into the sphere of publicity at the cultural level. Today, both models are combined differently and form an integral part of European legal practice that provides a legal guarantee for exercising freedom of religion as a fundamental human right. That is how the system of "plural inclusion of faiths and worldviews" is explained."

\subsection{MODELS OF STATE-CHURCH RELATIONS IN THE INDIVIDUAL EU MEMBER STATES}

Nowadays we can speak about the European pattern of church-state relations. The European dimension can be found in (1) protection of individual rights and freedoms of religion, (2) incompetence of the state in religious matters, that is, recognition of the independence of

21 Ibid. An interesting viewpoint about French secularism is the that cited by Baubérot, who considers it endangered from within for two reasons. First, because state neutrality hypertrophied in a way that can sometimes be interpreted as contrary to the 1905 Act, while other principles atrophied: separation, freedom of conscience and non-discrimination. Another reason is the intellectual simplification that has hit even the elite. That is why Baubérot calls for "renewed secularism". See: Baubérot, op. cit. in fn. 28, p. 20.

22 Bader, V., Religion and the Myths of Secularization and Separation, Religare working paper No. 8, p. 19. Available athttps://www. researchgate.net/publication/265679210-Religion-and-the-Myths-of-Secularization-and-Separation (19. 3. 2019).

23 Ibid., p. 24.

24 Štuhec, I. J., Sekularna Europa i novo pozicioniranje religije u društvu [Secular Europe and the new Placement of Religion into the Society], Nova prisutnost, Vol. 12, No. 1, 2014, p. 11. 
religion in all matters of its teaching and organization and (3) selective cooperation between the state and religions. ${ }^{25}$

However, beyond that, there are indeed noticeable differences in the European Union in understanding and practicing the laicism/secularity of individual countries. These differences are the result of different national histories and political cultures. ${ }^{26}$

France should be mentioned first. Namely, Art. 1 Section 1 of the Constitution of the French Republic reads as follows:

"France is an indivisible, lay, democratic and social republic. It ensures equality for all its citizens before the law, regardless of (...) religion. It respects all beliefs. (...)."

Such a determination of the mode of separation of state and church means, in the context of France and its acceptance of secularism as a firm ideological determinant of the Republic, the complete exclusion of religion from the public sphere. ${ }^{27}$ It is a consequence of tradition, of historical movements before and after the French Revolution, but it also contains exceptions that are a consequence of tradition as well (the example of the Alsace-Moselle department in which the state finances religious instruction for three recognized religions, since there is still a concord with the Holy See in force ${ }^{28}$ ). French laicism (secularism) has deep-rooted historical reasons dating back to the time before the French Revolution of 1787 . Specifically, the monarchy rested on religious principles and justifications (the theory of the divine rights of kings), which came especially to the fore during the coronation at the Reims Cathedral. As God's representative on earth, the king possessed political-religious power. The defence of the Roman Catholic faith was one of the king's basic duties. ${ }^{29}$ As a result of this commitment, the state prosecuted Protestants, causing further conflict in society. It is logical, then, that Art. 10 of the Declaration on the Rights of Man and the Citizen prescribing religious freedom created discord between the Revolution and the Catholic Church..$^{30}$ Subsequently, with the adoption of the new Constitution in 1791 and the complete dissolution (separation) of the state and the church, a specific French form of strict secularism was created that does not exist almost anywhere else in Europe. ${ }^{31}$ This went so far that a new calendar was created in 1793, according to which the year of creation of the Republic was the first year of the new calendar. ${ }^{32}$ However, due to historical trends, a more permanent dissolution of the church and the state resulted from the passage of the Civil Code in 1804, which clearly showed that the state had been deprived of the religious component in

Zrinščak, op. cit., fn. 14, p. 507.

Bižaca, M.; Parlov, M., Laička država, religija i Crkva [Secular State, Religion and Church], Crkva u svijetu, Zagreb Vol. 50, No. 3, 2015, p. 396.

7 See: Bodrožić, I., Crkva - nacija - država [Church - Nation - State], Nova prisutnost, Vol. 1, No. 2, 2002, p. 260. "It was not uncommon that believers and the Church were criticized for not being sufficiently committed to building the earthly society; on the other hand, there are attempts to push the Church out of influence in social life and keep it under constant control, accusing it of interfering in politics." Ibid.

Baubérot, J., La laïcité française : républicaine, indivisible, démocratique et sociale, Cités Vol. 52, No. 4, 2012, p. 12.

Baubérot, J., Two Thresholds of Laicization, in: R. Bhargava (ed.), Secularism and its critics, Oxford 1998, p. 94.

Ibid., p. 96.

The state approaching the French concept of secularism, that is, its church-state relationship is Slovenia (remark by the author).

Baubérot, op. cit., in fn. 29, p. 99. 
its foundations since its entry into force. ${ }^{33}$ According to Bauberot, French secularism/laicism is: republican, indivisible, democratic and social. ${ }^{34}$ However, there are some who think differently. "The French model of understanding and practising the separation of Church and State, traditionally inspired by Jacobin separatism, with some inconsistency (such as some support for Catholic schools), seeks a layman's interpretation of the relationship between state and religion, or the practice of emphasized privatization of religious beliefs and religious institutions. This model, however, borders on discrimination in certain situations." ${ }^{35}$

The only countries in Europe that come close to France in their constitutional orders (and which, along with France, are the only countries that do not have any form of religious instruction in public schools) are Slovenia and Albania. ${ }^{36}$ However, there are other models of the relationship between the secular state and religious communities, in which the secularity of political institutions does not prevent but promotes respect and cooperation with all religious communities for the benefit of the entire social community. "Here we can mention Germany and Austria, where churches and religions are generally perceived as an important interlocutor and contributor to the state in building a better society. Not to mention concordat states, for example Italy, whose constitution still mentions God and a specific religion.

Worth mentioning is also the case of the plural societies of Norway and Denmark, founded on respect for religious freedom and equality with their national churches, and the case of a highly secularized England, in which the guaranteed freedom of religion and worldview still does not exclude the royal sovereign from being the formal head of the Anglican Church." ${ }^{37}$ Indeed, in England, jurisprudence has concluded that "English society is predominantly secular and it is impossible to claim today that Christianity is a part of English common law." ${ }^{38}$ All this despite the fact that the King is the head of the Anglican Church, that parts of ecclesiastical law must be adopted by parliament when they have the same power as the acts of Parliament, and that parishioners enjoy certain statutory rights and bishops sit in the Upper House of Parliament. ${ }^{39}$

An analysis of the relationship between the state and the church points to two facts. First, these models are for the most part historically shaped and reflect the history of state-church relations in a specific country, which means a history of cooperation, but also a history of conflict, especially in the periods when capitalist systems and nation-states were formed. Secondly, models change under the influence of different processes, one of the most important being the guarantee of human rights and the principle of non-discrimination. ${ }^{40}$

33 Ibid., p. 103.

34 Baubérot, op. cit., in fn. 28.

35 Ibid. Green also states that the principle of laicism is intended to diminish the influence of religions and religious communities, especially in the public. See in: Green, L. N., Religion et ethnicité. De la comparaison spatiale et temporelle, Annales, Vol. 57, No. 1, 2002, p. 127.

This group could include Bulgaria, which does not have religious instruction as a separate subject, but religion is studied through other subjects, with an emphasis on the study of Orthodoxy. See in: Pepin, L., Teaching about Religions in European School Systems, London, 2009, p. 21.

Bižaca; Parlov, op. cit. in fn. 26, p. 397.

38 Sandberg, R., Religion, Law and Society, Cambridge University Press, Cambridge, 2014, p. 54.

39 Ibid., p. 122. 


\section{SECULARITY OF THE CROATIAN CONSTITUTIONAL STATE}

One newspaper article takes ${ }^{41}$ the following view: "In our society, secularism has become an ideology, a political project within which there is often no tolerance. An exclusive stance of martial secularism is taken that there is no place for religion within our constitutional order in the public sphere. From such an interpretation of Art. 41 of the Constitution then standpoints are deduced (substantiated weakly or not at all by scientific and professional arguments) about the incompatibility of the so-called Vatican treaties with the Constitution, the inadmissibility of confessional religious instruction in public schools, etc. Consistent acceptance of such an interpretation would also mean a ban on religious content in public places, a ban on religious services in prisons, etc. Generally speaking, the acceptance of such an interpretation of Art. 41 of the Constitution and such a definition of a "secular state" would mean a complete redefinition of the relationship between church and state in the Republic of Croatia, but, in my opinion, in an unconstitutional way."

It is necessary now to analyze the position quoted. Namely, in our public discourse, the position is taken that the only valid interpretation of the secular state is the content of Art. 41 of the Constitution, and the relationship between church and state, is the one that is in force in France. That is, that absolute separation of church and state is necessary and that there is no place for religion in the public sphere. ${ }^{42}$ Religion is a private matter. This model requires that the state neither support nor interfere with any religion. Also, this model according to Fox is the most extreme because it does not allow any state interference in religion or vice versa. The correctness of this attitude is argued by reference to the provision of Art. 41 of the Constitution, which "stipulates that church and state are separate." Of course, that is correct. However, this is not all that is regulated by Art. 41 of the Constitution. I would like to remind of the text of Art. 41 of the Constitution which reads as follows:

"All religious communities shall be equal before the law and separate from the state.

Religious communities shall be free, in compliance with the law, to publicly conduct religious services, open schools, colleges or other institutions, and welfare and charitable organizations and to manage them, and they shall enjoy the protection and assistance of the state in their activities."

It should be emphasized that it is undoubtful that the Republic of Croatia is a secular state in which the principle of separation of state and church applies. However, what does it mean that the Republic of Croatia is a secular state? In each state, the question of church-state relations is important. The answer to the question what the relationship between church and state

41 Staničić, F., Sekularizam je u Hrvatskoj politički projekt [Secularism is a Political Project in Croatia]. Available at https://www.vecernji. $\mathrm{hr} /$ vijesti/sekularizam-je-u-hrvatskoj-politicki-projekt-1200655 (19. 3. 2019).

42 "The misunderstanding between France and Germany stems from two opposite perceptions of religion in public space. In order to understand its scope, it is necessary to remind ourselves of three common models of relations between religion and state in the European Union: the model of the state church (England, Denmark and Finland), the so-called "strict" separation of church from the state (France, Netherlands, Ireland) and the so-called "separation-cooperation" model (Germany, Belgium, Austria, Spain, Italy...). The latter category is often misunderstood by French jurists because they are accustomed to thinking in the framework of worldliness, with the tendency to equate "separation" and "the law on the separation of the church from the state of 1905", and "separation" and "private sphere"." Rambaud, T., Odvojenost crkve od države u Njemačkoj i Francuskoj: komparativna analiza [The Separation of Church from the State in Germany and France: A Comparative Analysis], Političke analize, Vol. 15, No. 4, 2013, p. 3. 
is like also represents the determination of the status of religious communities in the territory of the state, as well as the establishment of freedom of religion as one of the fundamental human rights. But Rambaud's analysis of foreign legal literature, especially German, Austrian and Belgian, shows that the term "separation" is used to denote those relations between the state and the church that belong both to public law and contract law. In these conditions, the question of the existence of such a separation of the church from the state that is not limited to the French model arises, doesn't it? ${ }^{43}$

\subsection{ABOUT THE TERMS “SECULARISM”, "SECULAR” AND “SECULARIZATION"}

What do the terms "secularism" and the related terms "secular" and "secularization" mean? Many authors point out that it is not entirely clear what is meant by the term secularism since there are numerous "formulas" used under the name of secularism. ${ }^{44}$ Secularism, obviously, represents a problem in public life by itself.

Casanova states that all three concepts of "secular", "secularization" and "secularism" are obviously related, but used in different academic, sociopolitical and cultural contexts. ${ }^{45}$ The "secular" according to him became the central modern category - theological-philosophical, legal-political and cultural-anthropological - in order to construct, codify, understand and experience a world or reality that is separate from "the religious". ${ }^{46}$ "Secularization", according to Casanova, represents the actual or alleged empirical-historical sequence of the transformation and differentiation of the institutional spheres of the "religious" from the "secular" ${ }^{47}$ According to Casanova, "secularism" refers to the whole range of modern secular worldviews and ideologies, but it can also be seen as a state principle. ${ }^{48}$

Perhaps indeed it was Casanova who most clearly demarcated the terms "secular", "secularization" and "secularism" by stating that "secular" represents the central modern epistemological category, that "secularization" represents an analytical conceptualization of the historical processes of the modern world, and that "secularism" represents a worldview and ideology. ${ }^{49}$ That is to say, secular basically represents what is not religious. In this context, the historical self-understanding of secularism has the function of affirming the superiority of our modern secular understanding today about the supposedly prior and therefore more primitive religious forms of understanding. To be secular means to be modern, which implicates that being religious somehow means that such a person is not completely modern yet. ${ }^{50}$ The function of secularism, as a historical philosophy, and therefore an ideology is to transform a particular

\footnotetext{
43 Ibid.

44 Taylor, C., Modes of Secularism, in: Bhargava. R. (ed), Secularism and its critics, Oxford 1998, p. 31.

45 Casanova, J., Secular and Secularisms, Social Research, Vol. 76, No. 4, 2009, p. 1049.

46 Ibid.

47 Ibid., p. 1050

48 Ibid., p. 1051.

49 Casanova, J., The Secular, Secularizations, Secularisms, in: Calhoun, C.; Jurgenmayer, M.; VanAntwerpen (eds.), fn. 63, p. 54 and Casanova, op. cit. in fn. 43, p. 1049.

Ibid., p. 59.
} 
Western Christian process of secularization into a universal theological process of human development from belief into unbelief, from a primitive irrational or metaphysical faith into a modern rational post-metaphysical secular consciousness. ${ }^{51}$

Accordingly, Casanova distinguishes three different ways of being secular: a) ordinary secularity, which is a phenomenological experience of living in a secular world and a secular age, where it is quite common to be religious; b) self-sufficient and exclusive secularity, which represents the phenomenological experience of living without faith as a normal, quasi-natural, and unquestionable condition; and c) secularist secularity, which is a phenomenological experience of a condition in which a person is not only passively free but is literally "liberated" from religion, which is a prerequisite for human autonomy and progress. ${ }^{52}$

Likewise, we can define the idea of secularization as an idea that represents a trend, a general tendency to create a world where faith is less important, and different forms of secular worldview and secular institutions are more important. ${ }^{53}$ What is, then, secularism? Its meaning varies with the cultural circle and the context in which it is mentioned, somewhere it means exclusively tolerance, somewhere it means the complete exclusion of religion from the public sphere, and somewhere it signifies only the separation of church and state. Therefore, the first thesis I put forward is that secularism (as well as secularity) does not have a unique meaning in all countries and/or legal circles. The second thesis I put forward is that secularism represents, as Casanova calls it, a worldview, ${ }^{54}$ which can be distinguished not only as a state principle but also as an ideology. ${ }^{55}$

Besides, it should be noted that many believe that secularism is a product of the Christian world and should not be imposed on other cultures at all. ${ }^{56}$ However, while it is true that secularism is of Christian roots, it is wrong to think that it cannot be valid in post-Christian societies, ${ }^{57}$ and it is wrong to think that it is a vaccine for religious conflicts. ${ }^{58}$

Throughout the Christian era, the key question was what kind of relationship will the church(es) have with politics and the state. It is the question that can be followed from the first century AD onwards. It has been delineated through the centuries of struggle between the papacy and imperial power, and it was very rarely that the separate-but-equal status was achieved that would last for a long period of time. ${ }^{59}$ The religious wars that ravaged Europe through the sixteenth and early seventeenth centuries contained apart from a religious com-

\footnotetext{
51 Ibid.

52 Ibid., p. 60.

53 Ibid., p. 10.

54 Casanova, op. cit., in fn. 45, p. 1049.

55 Ibid. Turner also believes that laicism (the French form of secularism) is an ideological principle that is woven into French society and makes an inseparable part of political and social discussions concerning religion. See: Turner, E., Laïcité in Contemporary France: Analyzing the Implementation and Retention of Religious Programming on Publically Supported Television, p. 1, retrieved from: http://www.dv41ns1sk/content/Lai\%CC\%88cite\% CC\%81\%20in\%20Contemporary\%20France--Turner.pdf.n (7. 6. 2019).

56 Taylor, op. cit. in fn. 42. p. 31.

57 Ibid., pp. 31-37.

58 Calhoun, C.; Jurgenmayer, M.; VanAntwerpen, Introduction, in: Calhoun, C.; Jurgenmayer, M., VanAntwerpen (eds.), Rethinking secularism, Oxford 2011, p. 9.

Bader, op. cit. in fn. 20, p. 14.
} 
ponent a state-building component as well. In other words, they were spreading the power of a secular state, even though they were fought in the name of religion. They represented basically a path of creating a relatively strong secular environment in Europe after the Westphalia peace, because it was the only way to overcome the imposed religious conformance. ${ }^{60}$ It is these conflicts that, as Casanova pointed out, basically made Europe secular. ${ }^{61}$ The secularism, i.e. the separation of church and state was basically invented by "Latin Christianity" ${ }^{62}$ Secularism and the privatization of religion occur as the logical end of the evolution of faith, in which faith is finally revealed to be what it really is - a matter of subjective experience. ${ }^{63}$

Until the 1990s, the opinion that religious pluralism had caused great problems through the centuries, but recently ceased to create structural problems in modern states was absolutely dominant in post-World War II political science, political philosophy and sociology of religion. Religiously motivated or legitimized wars were "behind us". The principle of religious tolerance is widely recognized, and the institutions and practices of tolerance have been deeply rooted. ${ }^{64}$ Accordingly, liberal, democratic, socialist, feminist or otherwise "progressive" political parties share the assumption that modern states are secular states that require a firm constitutional, legal, administrative, political and cultural separation from organized religion. ${ }^{65}$ In normative theory, especially in political philosophy, there was a widespread agreement on the principles of tolerance and religious freedom, in the sense that liberal-democratic regimes should be neutral to religions, that politics should be "secular", and that religious organizations and beliefs could exclusively have a role in private life or civil society. ${ }^{66}$ Also, it was "normal" to consider that modern states are "secularized" and that this requires complete separation of religion from other functionally differentiated social systems and organizations, especially from the political system and the state. ${ }^{67}$ This is of special importance for minority groups. Otherwise, minority groups might feel that a) their understanding of things is different from that of the majority, b) that their view is either not understood or not accepted by the

6 Ibid., p. 15.

61 Casanova, J., Public Religions in the Modern World, Chicago 1994.

62 Joppke, C., Double Standards? Veils and Crucifixes in the European Legal Order, European Journal of Sociology, Cambridge, Volume 54, No. 1, 2014, p. 98.

Jukić states as well that “(...) secularization occurs within the Christian religion and weakens it internally, without a clear awareness of what it is really doing. Hence the conclusion that atheism represented the unbelief of unbelievers, while secularization becomes the unbelief of the faithful. Though admittedly belonging to the Church explicitly and in words, the secularized Christian denies this by his behavior and life." See in: Jukić, J., Sekularizacija društva i obitelji [The Secularization of Society and Family], Obnovljeni život, Volume 51, Nr. 6, 1996, p. 628. The same author points out that "in that initial secularization of Christianity, its main causes were (are) in the Church itself, and not in society as it is the case today. For the Church secularized itself, in the first place when it adopted Roman law and made it the fundamental principle of its internal organization.” See in: Jukić, J., Kršćanstvo i sekularizacija [Christianity and Secularization], Diacovensia, Vol. 8, No. 1, 2000 , p. 70. Štuhec states that "Christianity is one of the creators of secularization after Jesus' famous saying: Render to Caesar the things that are Caesar's, and to God the things that are God's. Secularization is not considered a negative phenomenon, but rather a prerequisite for distinguishing between the sphere of spirit and the world and, consequently, between the world and spiritual authority." See in: Štuhec, I. J., Sekularizacija kot priložnost za novo religioznost, Bogoslovni vestnik, Vol. 72, No. 4, 2012, pp. 609-618.

63 Ibid.

64 Bader, op. cit., fn. 20, p. 16.

65 Ibid.

66 Ibid.

67 Ibid. 
majority; and d) that the minority is systematically not listened to. That is why secularism, in some form, is necessary for the democratic life of religiously pluralistic societies. ${ }^{68}$

According to Kaufmann, secularization can be divided into the following types:

1. "Secularization as a process in which religion is increasingly losing its meaning. The loss of meaning of religion can be explained both from the point of view of emancipation and from the cultural-critical standpoint.

2. Secularization as pushing out of the ecclesiastical authority from the realm of secular authority, that is, of secular power. It is a modern development of the distinction between spiritual and worldly power which was legally enacted by the Worms Concordat, whereby the area of state authority has been further expanded, for example to the field of science and art. This can be perceived as the loss of the controlling role that the Church played in society.

3. Secularization as a simultaneous process of the corrupting and preserving of Christian achievements within the secular common good. It primarily refers to the equality of all people within the framework of human rights, as well as to the care of the poor in the context of the welfare state. In a secular society, however, we can still find strong traces of Christianity. Rendtorff talks about Christianity outside the Church.

4. Secularization as a prerequisite for the demythologization of religion and for the spiritualization of time.

5. Secularization as the separation of Christianity and the Church from the people." 69

According to Kaufmann, what is common to all these meanings, is that "it is an explicit relationship between religion and the new era". ${ }^{70}$

\subsection{ON THE RELATIONSHIP BETWEEN RELIGION AND POLITICS IN A SECULAR SOCIETY}

When it comes to secularism, i.e., a secular state, we need to answer at least three questions to define what it represents: First, since secularity basically means the separation of politics and religion, is it at all possible to separate religion from politics? Second, why should religion be separated from politics and what justifies such a separation? Third, what is the relationship between religion and politics after separation $?^{71}$ If we agree that it is necessary to separate religion from politics, in order to ensure the autonomy of both religion and politics, that is, to preserve equality in society, which is nowadays more or less widely accepted in Western society, we are left with a crucial third question: what is the relationship between religion and politics in a secular society like? To answer this question, it is necessary to distinguish between different aspects of secularism. It could be seen from the previous text that

68 Taylor, op. cit., in fn. 44, p. 46.

69 Kaufmann, Franz-Xaver, Kirchenkrise. Wie überlebt das Christentum? Freiburg, Basel, Vienna, Herder 2011, pp. 78-79. Štuhec, op. cit., in fn. 24 , p. 8.

$70 \quad$ Ibid.

71 Bhargava, R., What is Secularism for? In: Bhargava, R. (ed.), op. cit. in fn. 46, p. 488. 
secularism does not have the same meaning in all countries and/or cultures. By slightly simplifying the distinction between different aspects of secularism, it can be said that secularism means a complete and sharp separation of state and church, that is, a forthright rejection of any contact between religion and politics. ${ }^{72}$ This attitude towards secularism can be strong or mild. If strong, it undoubtedly creates mutual hostility since, according to this viewpoint of secularism, the secular state must be hostile to religion. ${ }^{73}$ If the attitude is mild, it does not require the total exclusion of religion. A certain level of contact is possible, but with keeping a distance between state and church; such a relationship between the state and the church can be called a principled distance. ${ }^{74}$ This attitude towards secularism can take two forms: the first that requires adherence to political neutrality in the sense that only when religion and politics have achieved an adequate distance can the state maintain the necessary neutrality towards the religious and the irreligious. The second seeks respect for the boundaries between politics and religion as politics and religion create their own areas of competence that must not overlap and must be respected. ${ }^{75}$

Accordingly, the possible division of forms of secularism may be as follows:

1. Ethical secularism that excludes all religions from state affairs,

2. Ethical secularism which demands from the state to maintain a principled distance from all religions,

3. Political secularism that excludes all ultimate ideas, including religion, from state affairs,

4. Political secularism which requires the state to distance itself consistently from all religious and other ultimate ideas. ${ }^{76}$

There are ideas that applying secularism should, if consistent, lead to secularization of society. Secularization as a phenomenon and / or trend should result from the strict separation of church and state. It should reduce the role of faith in states that consistently enforce strict separation of church and state. However, many authors believe that the thesis about the inevitable reduction of religious beliefs and practices resulting from the practices of Western European countries is wrong. ${ }^{77}$

However, as Štuhec points out, "the above mentioned did not cause the extinction of religion, as announced by some sociologists and philosophers, but its traces can be seen at different levels. Sociologically speaking, religion is not extinct but has reshaped its manifestations within the secular world. In this way, it has also changed its modes of manifestation and presence. Such a transformation of religion points to its vitality and power to survive in three

$72 \quad$ Ibid., p. 493.

73 Ibid. Hostility can be interventionist and non-interventionist. In the interventionist aspect of hostility, the state actively discourages religion. In the non-interventionist form, religion is untouchable, and secularism becomes the doctrine of political taboo - it forbids contact with certain activities.

Ibid.

75 Ibid., pp. 493-494.

76 Ibid., p. 494.

77 Bader, op. cit., in fn. 22, p. 19, Sandberg, op. cit. in fn. 38, p. 57.

Jukić states that the causes of secularization are social differentiation, rationalization of life and society, processes of urbanization and industrialization, individualization of people in modern society and contemporary pluralism. See in: Jukić, op. cit. in fn. 60, p. 630-632. 
directions: institutional transformation and prevalence, the abundance of the religious, and its partial radicalization." 78

Thus, it would be wrong to believe that the importance of religion in today's world is less than it used to be. In the global political arena, religion is and remains an important political and social factor. This is illustrated by the examples of the growth of so-called religious fundamentalism in the USA (one of its most famous branches is the Moral Majority Movement), the Islamic Revolution in Iran in 1979 and even current disputes between the so-called Islamist and so-called modernist forces in many Arab countries. ${ }^{79}$ The public perception of the extraordinary political role of religion was especially pronounced after the terrorist attack in New York in 2001. Politically it may be less intriguing, so it is less discussed in the media, but the growth of Pentecostalism in the world, and especially in Latin America and Africa, is very interesting. The image of the great role of religion is also associated with post-communist countries, and it has become customary to use the term revitalization of religion to describe the religious situation, at least in the immediate post-communist era in most of those countries. ${ }^{80}$ Religion, as an organized form of faith, is once again becoming, if it ever ceased to be, an important aspect of human lives, of their sense of belonging to a particular group, etc. As a particularly illustrative example, we can mention Turkey, where the increasing influence of religion on political life can be observed, although it was the state which, along with France, was cited as an example of a secular state. As the well-known sociologist Berger put it nicely, "with some important exceptions (...), the world is as religious as it has always been, and in some places more religious than ever. However, this does not mean that there is no secularization; it just means that this phenomenon is by no means a direct and inevitable result of modernization." $" 1$

Based on all mentioned above, I believe that these terms can be clearly distinguished. Secularity is a form of social (legal) order and a state of separation (more or less pronounced) of the state and church. Secularization is a process ${ }^{82}$ of achieving the secularization of society, i.e. a situation in a society in which religion and religious organizations lose their meaning and importance. Secularism represents the ideology (or in its more lenient version the political agenda) through which a secular society is sought. The more pronounced or more severe the secularism, the greater separation of state and church (the secularity) will be. Accordingly, depending on the degree of acceptance of secularism as an idea or political agenda, we can dis-

78 Štuhec, op. cit. in fn. 24, p. 9.

79 Zrinščak, op. cit. in fn. 14, p. 499.

$80 \quad$ Ibid. p. 500.

81 Berger, P. L., The 2000 Paul Hanly Purfey Lecture. Reflections on the Sociology of Religion Today, Sociology of Religion, Cambridge Vol. 62, No. 4, 2001, p. 445.

82 "The first attempt to define secularization was encountered as early as 1955 by the American sociologist of religion H. W. Pfautz, who even tried to numerically validate this phenomenon in a specific social context. For him, secularization is a general social process, under whose influence not only religious but also economic and political institutions come and therefore become completely secular. Another sociologist, J. M. Yinger, argues that secularization signifies a phenomenon that puts a person of today in the position to make a growing number of his or her decisions in daily life without having to directly relate to religion and without necessarily invoking religion. In other words, the process of secularization in its content equals the process of losing the social value of a religion and its traditional social role". Jukić, J., Teorije ideologizacije i sekularizacije [Ideologization and Secularization Theories], in: Grubišić, I. (ed.), Religija i sloboda - Religijska situacija u Hrvatskoj 1945-1990 [Religion and freedom - A Religious Situation in Croatia 1945-1990], Split, 1993, p. 37.

Jukić claimed that all developed countries were completely secularized, and that the countries of the Third World and the postcommunist order were entering equally rapidly into this horizon of worldliness. See in: Jukić, op. cit. in fn. 62, p. 623. 
tinguish several models of state-church relations. French authors also state that the principle of laicism was used as a means of governing, as a way of promoting the ideals of the French national tradition. ${ }^{83}$ Similarly, Jukić states, when he writes that secularization "expresses the historical process of recognizing and accepting a society in its secular reality", while secularism "signifies the closure of that society to its complete ideological sufficiency". According to Jukić," (...) secularization is acknowledgment of the possibility of the secular meaning of the world, and secularism is first and foremost a worldview that eliminates any possibility of supernatural revelation in that world." 84

\subsection{THE MODEL OF STATE-CHURCH RELATIONS IN THE REPUBLIC OF CROATIA}

First and foremost, the supra question must be answered: Is the principle of separation of state and church a constitutional principle? Considering the relevant constitutional provisions governing the status of religious communities, the impact of personal religious choice on the freedoms and rights of citizens, the right to freedom of religion, and the prohibition on restricting the freedom of religion, it is clear, that the framers of the Constitution have paid exceptional attention to faith (personal) and religion (organized). As already stated, the constitutional text forms a whole and thus should be interpreted in that way. In this context, I am of the opinion, that it is impossible to observe Art. 41 of the Constitution separately from Art. 1 of the Constitution, which defines the Republic of Croatia as a unitary and indivisible democratic and social state in which power originates from the people and belongs to the people as a community of free and equal citizens. In addition, I am of the opinion, that Art. 41 of the Constitution should also be considered in conjunction with Art. $3^{85}$ of the Constitution, by which essential values of the Croatian constitutional order are established, including equality and rule of law. In order to ensure that all citizens are equal (the basis for the existence of the Republic of Croatia as a democratic state), the state must be neutral towards all religions, that is, it must enable everyone to enjoy equal rights. This also arises from the understanding of the principle of freedom of religion (Article 40 of the Constitution), which is also required by the state. For this reason, I believe it is indisputable that the principle of separation of state and church is a constitutional principle, that is, "Croatia would not remain what it is" if this principle were removed from the Constitution.

Secondly, it has been previously reported that there are three general models of statechurch relations in theory (and in practice): 1) the model of state or national churches, 2) the cooperative or concordat model, and 3) the model of the strict separation of church and state. It is clear, that the Republic of Croatia does not belong to the model of state or national churches like Denmark or the United Kingdom. However, to which of the other two models does it belong?

83 See in: Zoller, E., La Laïcité aux Etats-Unis ou la Séparation des Eglises et de l'Etat dans la Société Pluraliste', in: Zoller, E. (ed.), La Conception Américaine de la Laïcité, Dalloz-Sirey, Paris, 2005, p. 4.

84 Ibid., pp. 623-624.

85 "Freedom, equal rights, national and gender equality, peace-making, social justice, respect for human rights, inviolability of ownership, conservation of nature and the environment, the rule of law and a democratic multiparty system are the highest values of the constitutional order of the Republic of Croatia and the basis for interpreting the Constitution." 
The constitution truly and completely stipulates the separation of the state and the church (Article 41, paragraph 1). According to the basic Fox model shown, this would mean that in the Republic of Croatia there is a system of separation that represents state neutrality towards religion in which the state, at least officially, does not favor any religion nor does it restrict the presence of religion in the public sphere either. This is not Fox's other basic model of laicism, which states that not only does the state not support any religion, but it also limits the presence of religion in the public sphere. ${ }^{86}$ However, when looking at paragraph 2, Art. 41 of the Constitution, we can see that in the Republic of Croatia, neither of the above two basic Fox models is applied.

If we look carefully at Art. 41, paragraph 2 of the Constitution, we shall see that the Constitution stipulates the obligation of the state to assist and protect religious communities in their activities. This fact clearly implies that the Republic of Croatia cannot belong to the model of strict separation, that is, the separation model as developed in France, which many supporters of the thesis on secular organization of the Republic of Croatia use as the only valid model of secularity, equating secularism in its extreme ideological-political meaning with secularity. Of course, this does not mean at the same time, that the state and the church are not and should not be separated since the Constitution prescribes the separation of religious communities and the state. However, it is about separation in terms of the inability of religious communities to influence the organization and functioning of the state, as well as the inability of the state to influence the organization and functioning of religious communities. ${ }^{87}$ Therefore, according to the constitutional order of the Republic of Croatia, interference of the church in the internal affairs of the state is not possible, as it is not possible for the state to interfere in the internal affairs of the church. In everything else, the mandatory cooperation on the part of the state is possible and necessary.

Relatively shortly before this paper was finished, the Constitutional Court of the Republic of Croatia issued its ruling U-I-4504/2010 of 18 December $2018^{88}$ rejecting the proposal to initiate proceedings for reviewing the conformity with the Constitution of Article 13 of the Law on the Legal Status of Religious Communities. ${ }^{89}$ In the said decision, the Constitutional Court pointed out:

"The Constitutional Court first establishes that the allegations made in the proposal of the proponent can in essence be reduced to the position according to which it is only the absolute separation of state and church that is in conformity with the Constitution, regardless of any other circumstances, because in their understanding any other arrangement was contrary to the constitutional principle of separation of religious communities from the state.

The Constitutional Court notes that such a position is based on an isolated interpretation of Article 41, paragraph 1 of the Constitution, without taking into consideration paragraph 2

86 Fox, op. cit., in fn. 16, p. 385.

87 As Bodrozic notes, "if the Church and the state are autonomous and independent, it does not mean that they must be separated and opposed, but that both should be at the service of man and his spiritual and material welfare. Man becomes the place of the meeting and working together of the Church and the state, and honest dialogue is the only correct method in their mutual relations." See in: Bodrožić, op. cit. in fn. 33, p. 262.

Available at www.usud.hr (19. 3. 2019), t. 9. 
of the same Article of the Constitution. Namely, according to Article 41 para. 2 of the Constitution, religious communities enjoy the protection and assistance of the state in their activities. It follows from this provision that the separation of state and religious communities is not absolute."

In my view, two things are discernible from the provision of Art. 41 of the Constitution: first, that in the Republic of Croatia the state and the church are separate, and second "that the duty and obligation of the state to protect religious communities and assist them in their activities has been established by the provision of Art. 41 para. 2 of the Constitution. Accordingly, in the Republic of Croatia a cooperative or concordat model of church-state relations is in force." 90

The German model based on "institutionalized cooperation" can serve as a "roadmap" in understanding the principle of separation of state and church in the Republic of Croatia". ${ }^{91}$ Namely, in German law, religious communities have the status of legal persons. The Federal Constitutional Court considers that "this status must strengthen the independent position of the church and its independence from the state." It is clear from the case-law of this court that recognition of a legal personality has a threefold effect:

1. In Germany, the separation of church and state is not radical. The German constitution provides for adequate institutional guarantees;

2. the status of a corporation with a legal personality emphasizes and acknowledges the public and social role of mainstream religions;

3. the status of a corporation with a legal personality presupposes a harmonious relationship between the two sovereign partners. By giving them the status of a legal entity, the state is ready to cooperate with religious communities. ${ }^{92}$

"Concerning the manner, in which the provision of Art. 41 para. 1 of the Constitution "(...) and are separated from the state" should be interpreted, as an illustration, we may use a decision of the Constitutional Court of the Republic of Croatia U-II / 2050/2012 of 13 November 2012, ${ }^{93}$ by which the Constitutional Court rejected the proposal to initiate the procedure for reviewing the conformity of the Regulation on the Internal Organization of the Ministry

90 Sokol; Staničić, op. cit., in fn. 14, pp. 44-45.

91 Rambaud, op. cit. in fn. 42, p. 7.

92 Ibid.

93 Available at www.usud.hr (29. 6. 2018). The relevant part of the decision reads as follows:

"11. It follows from all of the above stated that the legal basis for the establishment of the Military Ordinariate is contained in an international treaty (that is, it was established by an international treaty), while the establishment of a special organizational unit in the Ministry of Defense (and the Ministry of the Interior) for co-operation with the Military Ordinariate is provided for by a regulation (Ordinance) the enactment of which also results from an international treaty. 11.1. The Independent Support Section to the Military Ordinariate Office in the Republic of Croatia was established as an internal organizational unit of the Ministry of Defense on the basis and in accordance with the regulations of the Republic of Croatia (see paragraph 5 of the reasoning for the decision). It follows from the content of the impugned Article 163 of the Regulation that this Section has no authority to perform any religious activities (as claimed by the proponent), but is authorized to carry out tasks related to the implementation of the Ordinance, which, in essence, can be reduced to providing technical assistance at the Military Ordinariate and coordinating and organizing activities of the spiritual and religious content of the Ministry staff and members of the Armed Forces of the Catholic Religion. (...)

14. The Constitutional Court points out that the organizational and administrative form of implementation of an international obligation (the operation of the Military Ordinariate) is not determined by contract or law, but by the Regulation. The question whether the establishment of an independent department within the Ministry of Defense violated Article 41 of the Constitution cannot be answered in the abstract because the answer depends on the activities of that department. The petitioner failed to 
of Defense with the Art. 163 of the Constitution. This provision establishes an Independent Support Section for the Military Ordinariate Office in the Republic of Croatia (Military Ordinariate Office) within the Ministry of Defense of the Republic of Croatia. It was challenged on the ground that it did not comply with Art. 41 para. 1 of the Constitution. The Constitutional Court rejected the proposal and established "separation" from Art. 41 (1) of the Constitution as a two-way barrier." ${ }^{4}$ "It preserves the autonomy of the religious community from interference on the part of the state, but also has the task of preventing the interference of religious organizations in state affairs." 95

The principle of separation of religion from the state can be defined as "a type of legal relationship between church and state in which the latter, being neutral in reference to religion, does not behave in a particularly good or a particularly bad way towards any religious community and guarantees to each of them freedom of institutional organization and functioning." 96

\subsection{THE POSITION OF RELIGION IN THE PUBLIC SPHERE IN THE REPUBLIC OF CROATIA}

It should be emphasized that, very often, the debate on secularity of the Republic of Croatia in our country comes down to the debate on the position of religion in the public sphere. It is, therefore, necessary, at the end of this paper, to clarify the possibilities that exist regarding the position of religion in the public sphere. The debate on the position of religion in the public sphere should begin with the following sentence: "Faith, in liberal theory, appears primarily as an occasion for tolerance and neutrality." ${ }^{\prime 7}$ This orientation is reinforced by a) the determination of religion as a private matter, b) an epistemological approach to faith created by an attempt to evaluate right and wrong knowledge, c) the idea that a clear and unbiased distinction is possible between religion and the secular, and d) the view that faith is in some way a relic of the previous era. Specifically, the narrative of secularization is largely derived from the view of religion as mere superstition and something traditional and inherited from the past without a real foothold in the present day. ${ }^{98}$ From the foregoing, conclusions are drawn that faith should remain in the private sphere. These conclusions have been met with resistance, for example, by Habermas, who states that this is discriminatory and emphasizes further that religion is a valuable source and resource for democratic policies. ${ }^{99}$ As I have already shown, despite the secularization process, the influence of religion in the world has not diminished. In the pluralistic and democratic world, there is enough space both for the secular elements of

convince the Constitutional Court that the action of the department resulted in the impermissible influence of the church on state affairs and did not offer any arguments that could be discussed in this constitutional court procedure."

Sokol; Staničić, op. cit., in fn. 14, p. 44

Miloš, M., Hrvatske vjerske zajednice u (protu)većinskoj prizmi svjetovne države [Croatian Religious Communities in the (Counter) majoritarian Prism of the Secular State], Zbornik Pravnog fakulteta Sveučilišta u Rijeci, Vol. 35, No. 2, 2014, p. 660.

Rambaud, op. cit. in fn. 42, p. 4.

Calhoun, C., Secularism, Citizenship and the Public Sphere, in: Calhoun, C.; Jurgenmayer, M.; VanAntwerpen, J. (eds.), op. cit. in fn. 14, p. 77.

Ibid.

According to: ibid., p. 78. 
society and for the religious ones in the public sphere. As Calhoun points out, rethinking the notion of secularism does not mean abandoning the norms of righteousness or state neutrality regarding different faiths. On the contrary, it means efforts, through debate in the public sphere, to detect and establish a common view. ${ }^{100}$ I would also add the following: the role of organized religion is certainly to comment responsibly on social events because its presence in the public space is not only its right but also its obligation.

As already stated, the key question might not be whether a country is secular or not, but the real debate should be whether it is "decent and/or liberal-democratic". Accordingly, it should be emphasized that the regulation of the rights of religious communities in the Republic of Croatia does not fully comply with the constitutional provisions. Specifically, our system has established several types of religious communities, depending on the rights they enjoy:

1. "The Catholic Church, whose position is governed by international treaties and which has a special, sui generis status within the Croatian legal system and to which, to a large extent, Croatian law does not apply;

2. religious communities that have signed special agreements with the state:

3. registered religious communities;

4. unregistered religious communities with the legal form of religious associations, the so-called emerging religious communities;

5. unregistered religious communities that do not even have the legal form of religious associations." 101

Under the regulatory framework, many religious communities are unable to exercise the rights exercised by other religious communities, which means violation of the proclaimed constitutional principle of equality of religious communities before the law. This is especially true of the position of those religious communities that have not, unlike the Catholic Church and 19 other religious communities, ${ }^{102}$ entered into special contracts with the state and thus achieved broad rights. Specifically, "there is a problem with the fact that the procedure for entering into these contracts is discretionary. Art 9 of the Croatian Law on the Legal Status of Religious Communities (ZPPVZ) stipulates that such a contract can be concluded. As a rule, when a legal provision stipulates that something can be done, it means that it does not have to be. Therefore, it is for the state to decide when, under what conditions and with which

100 Ibid., p. 88.

101 Staničić, F., The Legal Status of Religious Communities in Croatian Law, Zbornik Pravnog fakulteta u Zagrebu, 2/2014, p. 244.

102 Eight contracts were concluded with a total of 19 (nineteen) religious communities:

1. 20. 12. 2002 with the Serbian Orthodox Church (Official Gazette 196/03)

2. 20. 12. 2002 with the Islamic Community (Official Gazette 196/03 and 86/14 - correction)

3. 4. 07. 2003 with the Evangelical Church in the Republic of Croatia and the Reformed Christian (Calvinist) Church in Croatia (Official Gazette 196/03)

4. 4.07. 2003 with the Evangelical Pentecostal Church in the Republic of Croatia (representing two more churches: the Church of God in the Republic of Croatia and the Union of Christ Pentecostal Churches in the Republic of Croatia), the Christian Adventist Church in the Republic of Croatia (representing another church: Seventh-day Adventist Reform Movement) and the Union of Baptist Churches in the Republic of Croatia (representing another church: the Church of Christ) (OG 196/03)

5. 29. 10. 2003 with the Bulgarian Orthodox Church in Croatia, the Croatian Old Catholic Church and the Macedonian Orthodox Church in Croatia (OG 196/03)

7. 27. 10. 2011 with the Jewish Religious Community Bet Israel in Croatia (OG 4/12)

8. 12. 09. 2014 with the Union of Churches "Word of Life", the Church of the Full Gospel and the Protestant Reformed Christian

Church in the Republic of Croatia (OG 112/2014). 
religious community it will conclude a contract on matters of "common interest" because the law is silent on this. It is, therefore, at the discretion of the State to enter into contracts with religious communities. Such a legislative solution leads to the situation that not all religious communities are equal before the law because there is no legal certainty regarding the conclusion of the said contacts, that is, there are those religious communities that have concluded the contract and those who, without clear criteria, were not enabled to do so. This solution creates religious communities of different legal status: those who enjoy (almost) all the rights enjoyed by the Catholic Church and those who are denied those rights. Religious communities that have signed a contract with the state are in a much more favorable legal position than those who have not. It is obvious, therefore, that we cannot speak about the equal position of all religious communities before the law in the Republic of Croatia, which is a clear violation of Art. 41 (1) of the Constitution of the Republic of Croatia." 103

This problem was also recognized before the European Court of Human Rights in the Savez crkava "Riječ života" i drugi protiv Hrvatske (Union of Churches "Word of Life" and Others v. Croatia) (2010). The petition to the European Court of Justice was filed by the Union of Churches "Word of Life", the Church of the Full Gospel and the Protestant Reformed Christian Church in the Republic of Croatia. The Court established a violation of Article 14 in conjunction with Article 9 of the Convention (discrimination by religion). ${ }^{104}$

Therefore, in my opinion, it would be better to stop exhausting ourselves by useless debates about the (in)secularity of the Republic of Croatia and the (in)permissibility of letting the faith step in the public sphere, and start addressing issues of inequality in the position of religious communities.

\section{CONCLUSION}

In this paper, I wanted to show, first, that the term "secularism" does not have one meaning and that its meaning depends on several interrelated factors (constitutional/legislative order of the state, cultural circle, historical circumstances, etc.) and second, the understanding of secularism and its corresponding classifications. It is also important to point out the fact that it is difficult to find in any country a pure model of secularity. Research has shown that there is no pure model of secularism-laicism even in the countries commonly cited as such France and Turkey (although the situation has changed substantially in Turkey in the last ten years). It should be emphasized, as Casanova points out, that the key question in secularism is whether it represents a goal to itself, whether it is the ultimate value or a way of achieving another goal (democracy and equal civil and religious rights). ${ }^{105}$ If secularism is a goal in itself, or a final value, then it is clear, in Casanova's terminology, that it is the case of secularism as

103 Staničić, F., Treba li nam revizija ugovora sa Svetom Stolicom? [Do We Need a Revision of the Contract with the Holy See], Zbornik Pravnog fakulteta u Zagrebu, Vol. 68, No. 3-4, 2018, pp. 410-411.

104 See more in: Omejec, J., Konvencija za zaštitu ljudskih prava i temeljnih sloboda u praksi Europskog suda za ljudska prava-Strasbourški acquis [Convention for the Protection of Human Rights and Fundamental Freedoms in the Practice of the European Court of Human Rights - Strasbourg acquis], Novi informator, Zagreb, 2013, pp. 1313-1315.

105 Casanova, op. cit., in fn. 45, p. 1062. 
an ideology. On the other hand, if secularism is "just" a way to achieve some other legitimate goal, then it can be considered a statesman principle.

One of the important issues I wanted to analyze was the possibility of faith participating in the public sphere. I think that I have shown that, although there are countries where religion is considered a private matter and in which the constitution is set up to prevent any involvement of religion in the public sphere (France, Slovenia, Albania), such states form a minority. Namely, three basic models of church-state relations have been established in the world: the model of state or national churches, the cooperative or concordat model, and the model of strict separation of church and state (separation model). The third model is the rarest, and the most common is the cooperative or concordat model to which most European states belong, although some of the states that established this model have in their constitutions an explicit provision on separation of church and state.

The Republic of Croatia also belongs to the most common model - the concordat or cooperative model. This is true, indeed, despite the fact that Art. 41 (1) of the Constitution provides that the church and the states are separate (all religious communities are equal before the law and separate from the state) since Art. 41 para. 2 of the Constitution stipulates the obligation of the state to cooperate with religious communities and assist them in their activities. I have shown that the principle of separation of state and church from Art. 41 of the Constitution is a constitutional principle that determines the structure and essence of the Croatian constitutional state. Separation of the state and the church means, of course, that the Republic of Croatia is a secular state. However, this is not strict laicism (strict separation) in the sense of the French approach that would ban the participation of religion in the public sphere. It is about separation in terms of the inability of religious communities to influence the organization and functioning of the state, as well as the inability of the state to influence the organization and functioning of religious communities. Therefore, according to the constitutional order of the Republic of Croatia, it is neither possible for the church to interfere in the internal affairs of the state, nor is it possible for the state to interfere in the internal affairs of the church. In everything else, mandatory cooperation on the part of the state is possible and necessary. We should also accept the fact that the modern state is pluralistic in its world view, ${ }^{106}$ and that pluralism must include religious diversity and tolerance ${ }^{107}$. Also, the state and the churches must correct their views and enter into dialogue for the benefit of all citizens, and churches must be accepted as equal participants in public discourse, without any obligation that their standpoints must be accepted. ${ }^{108}$

Finally, I believe that it is important to properly regulate the relationship between religious communities and the state, regardless of how the state has formally stipulated the status of religion and religious communities in the constitutional text and its legislative system. In other words, if the state establishes a cooperative model of state-church relations, the fundamental question is whether it cooperates equally with everyone with whom it should, and if it establishes a system of strict separation of state and church, the fundamental question is

106 Malović, op. cit., in fn. 3, p. 437.

107 As Jukić states, tolerance is nowadays first and foremost a legal, constitutional category in the field of protection of fundamental human rights that have become an integral part of the mindset in civil societies. Jukić, J., Obilježja modernog društva [Characteristics of modern society], Obnovljeni život, Vol. 51, No. 4, 1996, p. 402. 
whether this rule applies to everyone. What is important is the acceptance of the simple fact that religious communities and other organized forms of religion and / or belief must be equal in exercising their rights guaranteed by the state.

\section{REFERENCES}

1. Bader, V., Introduction to secularism or democracy? Associational governance of religious diversity, Krisis, Journal for contemporary philosophy, Amsterdam, Vol. 9, No. 1, 2008, pp. 16-24.

2. Bader, V., Religion and the Myths of Secularization and Separation, Religare working paper No. 8, Available at https://www.researchgate.net/publication/265679210-Religion-and-the-Myths-of-Secularization-and-Separation (19. 3. 2019).

3. Baubérot, J., Two Thresholds of Laicization, in: R. Bhargava (ed.), Secularism and its critics, Oxford 1998.

4. Baubérot, J., La laïcité française: républicaine, indivisible, démocratique et sociale, Cités Vol. 52, No. 4, 2012, pp. 11-20.

5. Bhargava, R., What is Secularism for? In: Bhargava, R. (ed.), Secularism and its critics, Oxford 1998.

6. Berger, P. L., The 2000 Paul Hanly Purfey Lecture. Reflections on the Sociology of Religion Today, Sociology of Religion, Cambridge Vol. 62, No. 4, 2001, pp. 443-454.

7. Bižaca M.; Parlov, M., Laička država, religijai Crkva, Crkva u svijetu, Vol. 50, No. 3, 2015, pp. 395-401.

8. Bodrožić, I., Crkva - nacija - država, Nova prisutnost, Vol. 1, No. 2, 2002, pp. 257-264.

9. Brugger, W., On the Relationship between Structural Norms and Constitutional rights in Church-State-Relations, in: W. Brugger/M. Karayanni (eds.), Religion in the Public Sphere: A Comparative Analysis of German, Israeli, American and International Law, Berlin - Heidelberg - New York 2007.

10. Calhoun, C.; Jurgenmayer, M.; VanAntwerpen, J., Introduction, in: Calhoun, C.; Jurgenmayer, M.; VanAntwerpen, J. (eds.), Rethinkhing secularism, Oxford 2011.

11. Calhoun, C., Secularism, Citizenship and the Public Sphere, in: Calhoun, C.; Jurgenmayer, M.; VanAntwerpen, J. (eds.), Rethinkhing secularism, Oxford 2011.

12. Casanova, J., Public Religions in the Modern World, Chicago 1994.

13. Casanova, J., The Secular, Secularizations, Secularisms in: Calhoun, C., Jurgenmayer, M., VanAntwerpen, J., Introduction, in: Calhoun, C.; Jurgenmayer, M.; VanAntwerpen, J. (eds.), Rethinkhing secularism, Oxford 2011.

14. Casanova, J., Secular and Secularisms, Social Research, Vol. 76, No. 4, 2009, pp. 1049-1066.

15. Fox, J., Separation of Religion and State and Secularism in Theory and in Practice, Religion State and Society, London, Vol. 39, No. 4, 2011, pp. 384-401.

16. Green, L. N., Religion et ethnicité. De la comparaison spatiale et temporelle, Annales, Vol. 57, No. 1, 2002, pp. 127-144.

17. Joppke, C., Double Standards? Veils and Crucifixes in the European Legal Order, European Journal of Sociology, Cambridge, Vol. 54, No. 1, 2014, pp. 97-123.

18. Jukić, J., Teorije ideologizacije i sekularizacije, in: Grubišić I. (ed.), Religija i sloboda - Religijska situacija u Hrvatskoj 1945-1990, Split, 1993, pp. 11-65.

19. Jukić, J., Obilježja modernog društva, Obnovljeni život, Vol. 51, No. 4, 1996, pp. 387-406.

20. Jukić, J., Sekularizacija društva i obitelji, Obnovljeni život, Vol. 51, No. 6, 1996, pp. 623-640. 
21. Jukić, J., Kršćanstvo i sekularizacija, Diacovensia, Vol. 8, No. 1, 2000, pp. 69-87.

22. Kaufmann, Franz-Xaver, Kirchenkrise. Wie überlebt das Christentum? Freiburg, Basel, Wien, Herder 2011.

23. Malović, N., Laičnost - prilike i zablude, Crkva u svijetu, Vol. 50, No. 3, 2015, pp. 427-444.

24. Miloš, M., Hrvatske vjerske zajednice u (protu) većinskoj prizmi svjetovne države, Zbornik Pravnog fakulteta Sveučilišta u Rijeci, Vol. 35, br. 2, 2014, pp. 651-677.

25. Omejec, J., Konvencija za zaštitu ljudskih prava i temeljnih sloboda u praksi Europskog suda za ljudska prava - Strasbourški acquis, Novi informator, Zagreb, 2013.

26. Pepin, L., Teaching about Religions in European School Systems, London 2009.

27. Rambaud, T., Odvojenost crkve od države u Njemačkoj i Francuskoj: komparativna analiza, Političke analize, Vol. 15, No. 4, 2013, pp. 3-11.

28. Sandberg, R., Religion, Law and Society, Cambridge University Press, Cambridge, 2014.

29. Sokol, T.; Staničić, F., Pravni položaj Katoličke Crkve kao gospodarskog subjekta u pravu Europske unije i hrvatskom pravu, Zbornik Pravnog fakulteta u Zagrebu, Vol. 68, No. 3-4, 2018, pp. 31-60.

30. Staničić, F., The Legal Status of Religious Communities in Croatian Law, Zbornik Pravnog fakulteta u Zagrebu, Vol. 64, No. 2, 2014, pp. 225-254.

31. Staničić, F., Sekularizam je u Hrvatskoj politički projekt. Available at https://www.vecernji.hr/vijesti/ sekularizam-je-u-hrvatskoj-politicki-projekt-1200655 (19. 3. 2019).

32. Staničić, F., Treba li nam revizija ugovora sa Svetom Stolicom?, Zbornik Pravnog fakulteta u Zagrebu, Vol. 68, No. 3-4, 2018, pp. 397-429.

33. Špehar, H., Laičnost: etimologija i historijat, Politička misao, Vol. 48, br. 1, 2011, pp. 108-134.

34. Štuhec, I. J., Sekularizacija kot priložnost za novo religioznost, Bogoslovni vestnik, Vol. 72, No. 4, 2012, pp. 609-618.

35. Štuhec, Ivan Janez, Sekularna Europa i novo pozicioniranje religije u društvu, Nova prisutnost, Vol. 12, No. 1, 2014, pp. 5-22.

36. Taylor, C., Modes of Secularism, in: R. Bhargava (ed.), Secularism and its critics, Oxford 1998.

37. Turner, E., Laïcité in Contemporary France: Analyzing the Implementation and Retention of Religious Programming on Publically Supported Television. Available at: https://academiccommons.columbia. edu/download/fedora_content/download/ac:5dv41ns1sk/content/Lai\%CC\%88cite\%CC\%81\%20 in\%20Contemporary\%20France--Turner.pdf (7. 6. 2019).

38. Zoller, E., La Laïcité aux Etats-Unis ou la Séparation des Eglises et de l'Etat dans la Société Pluraliste, in: Zoller, E. (ed.), La Conception Américaine de la Laïcité, Dalloz-Sirey, Paris, 2005.

39. Zrinščak, S., Religija i društvo, in: J. Kregar et al., Uvod u sociologiju, Zagreb, 2014.

\section{INTERNET SOURCES}

1. Puhovski za Index: Hrvatska ustavno nije sekularna država, evo tri argumenta za to, https://www. index.hr/vijesti/clanak/puhovski-za-index-hrvatska-ustavno-nije-sekularna-drzava-evo-tri-argumenta-za-to/990914.aspx (19. 3. 2019).

2. Upravo nam je i šef katedre za ustavno pravo potvrdio kako je Hrvatska sekularna država, https:// www.telegram.hr/politika-kriminal/upravo-nam-je-i-sef-katedre-za-ustavno-pravo-potvrdio-kakoje-hrvatska-sekularna-drzava/ (19. 3. 2019). 
3. Ugledna profesorica ustavnog prava podučila Urednika Glasa Koncila: "Hrvatska je prema Ustavu sekularna država i točka”, https://net.hr/danas/hrvatska/ugledna-profesorica-ustavnog-prava-poducila-urednika-glasa-koncila-hrvatska-je-prema-ustavu-sekularna-drzava-i-tocka/ (19. 3. 2019).

4. Glas Koncila: Hrvatska nije "sekularna" država, http://hr.n1info.com/a245353/Vijesti/Glas-Koncila-Hrvatska-nije-sekularna-drzava.html (19. 3. 2019).

5. Dan kad su svi bili u krivu: Je li Hrvatska sekularna država, http://hrvatska-danas.com/2017/08/28/ dan-kad-su-svi-bili-u-krivu-je-li-hrvatska-sekularna-drzava/ (19. 3. 2019).

6. Sekularnost hrvatske države: Problem od kojeg bježe i lijevi i desni, http://www.novilist.hr/Vijesti/ Hrvatska/Sekularnost-hrvatske-drzave-Problem-od-kojeg-bjeze-i-lijevi-i-desni (19. 3. 2019).

7. Kakva Crkva u kakvoj Hrvatskoj? Prisutnost Crkve je legitimna činjenica - ali kakva ona treba biti?, https://www.glas-koncila.hr/kakva-crkva-kakvoj-hrvatskoj-prisutnost-crkve-legitimna-cinjenica-kakva-biti/ (19. 3. 2019).

8. Miklenić je u pravu da Hrvatska po Ustavu nije sekularna država, https://www.vecernji.hr/vijesti/ miklenic-je-u-pravu-da-hrvatska-po-ustavu-nije-sekularna-drzava-1190859 (19. 3. 2019). 
Frane Staničić*

\section{PRILOG RASPRAVI O REPUBLICI HRVATSKOJ KAO SEKULARNOJ DRŽAVI I POJMOVIMA SEKULARIZACIJE I SEKULARIZMA}

\section{Sažetak}

Autor u radu razmatra pitanje poimanja odvojenosti države i crkve u Republici Hrvatskoj. Navodi da se u hrvatskoj javnosti vodi rasprava o tome je li Republika Hrvatska sekularna država. Neki sudionici te rasprave tvrde da je Republika Hrvatska sekularna država, a neki tvrde suprotno. Kako bi analizirao odnos države i crkve u Republici Hrvatskoj autor najprije analizira ustavno određenje odvojenosti države i crkve. Potom analizira različite modele odnosa države i crkve kako bi dao teorijski okvir za svrstavanje Republike Hrvatske u odgovarajući model. Definira pojam "sekularizam" i razlikuje taj pojam od dva druga pojma: "sekularno" i "sekularizacija”. Kroz primjere i istraživanja drugih autora pokazuje da nema zajedničke definicije sekularizma i da ga nije moguće definirati na način koji bi bio primjenjiv u svakom pravnom sustavu. Autor pokazuje da oni koji tvrde da Republika Hrvatska nije sekularna država nemaju pravo. Međutim, također pokazuje da značenje koje "sekularisti” u Republici Hrvatskoj daju pojmu "sekularizam" na temelju kojega tvrde da je Republika Hrvatska sekularna država također pogrešno. Naime, sekularnost u hrvatskom kontekstu nema jednako značenje kao u Francuskoj - isključenje religije iz javne sfere. Republika Hrvatska je izgradila kooperacijski model odnosa države i crkve u kojem su država i crkva odvojeni, ali je država dužna surađivati i pomagati vjerskim zajednicama u njihovu radu.

Ključne riječi: $\quad$ sekularnost, sekularizam, sekularizacija, odvojenost crkve i države

\section{(1) $(9$}

This work is licensed under a Creative Commons

Attribution-NonCommercial 4.0 International License.

* Dr. sc. Frane Staničić, izvanredni profesor, Pravni fakultet Sveučilišta u Zagrebu, Trg Republike Hrvatske 14, 10000 Zagreb, Republika Hrvatska. Adresa e-pošte: frane.stanicic@pravo.hr. ORCID: https//: orcid.org/0000-0001-8304-7901. 